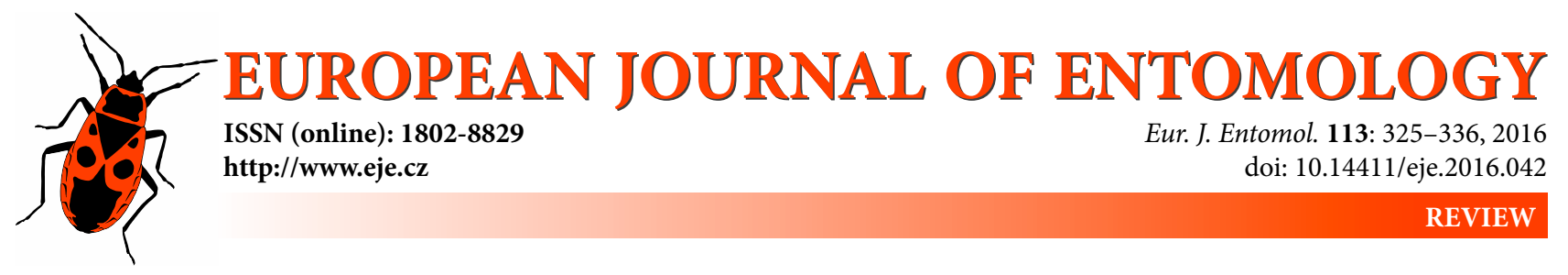

\title{
A synthesis of feeding habits and reproduction rhythm in Italian seed-feeding ground beetles (Coleoptera: Carabidae)
}

\author{
Federica tAlarico ${ }^{1}$, Anita GIGlo ${ }^{2}$, Roberto PIZZOLOTTO² and Pietro BRANDMAYR ${ }^{2}$ \\ ${ }^{1}$ Natural History Museum and Botanical Garden, University of Calabria, 87036 Calabria, Italy; e-mail: federica.talarico@unical.it \\ 2 Department of Biology, Ecology and Earth Science (DiBEST), University of Calabria, 87036 Calabria Italy; \\ e-mails: anita.giglio@unical.it, piz@unical.it, brandmayr@unical.it
}

Key words. Coleoptera, Carabidae, food choice, omnivorous, granivorous ground beetles

\begin{abstract}
Many species of carabid beetles are important pre- and post-dispersal seed feeders of herbaceous plants. Here we summarise data from dissections, field observations, rearing and "cafeteria" experiments on 55 granivorous and 188 omnivorous species that occur in Italy. We tested the hypothesis that seed feeding carabids are restricted to taxa with pronounced morphological adaptations for manipulating and crushing seeds in both the larval and adult stages. The feeding guilds of carabids were rearranged into the following groups: (i) strict predators with long mandibles and predaceous larvae, often depending also on non-prey food; (ii) omnivorous species with stout mandibles and larvae of a seed-eating morphotype; (iii) granivorous species, feeding only on seeds with larvae sometimes of the scarabeoid c-form type. The seed feeding carabids in the Italian fauna belong to the tribe Zabrini (Amara and Zabrus genera) and to all the Harpalinae (sub)tribes, from Anisodactylini to Ditomina. The time of reproduction seems to be associated with habitat preference; wetland or dry open land, rather than true granivorous versus omnivorous habits, but in stenophagous seed feeders, a phenological coincidence with particular plants is sometimes recorded.
\end{abstract}

\section{INTRODUCTION}

Carabid beetles are polyphagous and their feeding behaviour ranges from complete zoophagy to complete phytophagy, with most granivorous species falling somewhere in the middle of this continuum (Zetto Brandmayr, 1976, 1978, 1990; Hengeveld, 1980a, b, c, 1981; Brandmayr et al., 1990; Larochelle, 1990; Honek et al., 2003, 2006; Martinkova et al., 2006; Lundgren, 2009). Quantitative and qualitative studies on several carabid species involved in the biological control of several cropland pests (Luff, 1987; Lövei \& Sunderland, 1996; Kromp, 1999; Holland \& Luff, 2000) have shown their role as predators (Luff, 1987; Lövei \& Sunderland, 1996; Kromp, 1999; Holland \& Luff, 2000). In the temperate zone, these are the most important seed predators (Honek et al., 2003, 2005) in intensively managed agricultural landscapes (Saska et al., 2014). Granivorous carabids are important pre- and postdispersal weed seed predators, and in terms of agricultural ecosystem services are biological control agents of weeds (Mauchline et al., 2005; Jacob et al., 2006; Gaines \& Gratton, 2010; Kulkarni et al., 2015).

Many authors have studied the phytophagous habits of ground beetles. Forbes (1883) first recognized the granivorous preferences of many species and described three general feeding guilds based on morphological differences in the mouthparts. Zhavoronkova (1969) divided adult carabids into three feeding guilds: (1) strict predators (obligate zoophages); (2) predominant zoophages (more predaceous than phytophagous); (3) predominant phytophages (predaceous omnivores that consume more plant material than animal tissue).

Thiele (1977) classified carabids into three categories according to their manner of food intake: oligophagous predators, polyphagous predators and phytophages. Granivory was subsequently confirmed by numerous authors (Burmeister, 1939; Lindroth, 1949; Davies, 1953; Skuhravy, 1959; Dawson, 1965; Burakowsky, 1967; Johnson \& Cameron, 1969; Manley, 1971; Larochelle, 1990; Hůrka, 1992, 1998; Jørgensen \& Toft, 1997a, b; for a more complete list see Forsythe, 1982; Acorn \& Ball, 1991; Honek et al., 2003). Although adult feeding habits and food requirements are reasonably well known, little is known about granivory in larvae. Some morphofunctional studies have shown a relationship between morphology and feeding behaviour in the larval stage. Sharova (1960) defines some morpho-ecological types in the European temperate zone and places most Harpaline and Zabrine larvae with a phytophagous diet into the morpho-ecological types $\mathrm{V}$, VI, VII and VIII. Zetto Brandmayr et al. (1998) reduced these types into two simpler categories: a - spermopha- 
gous (seed predators); b - c-shaped harpalines, excluding the Ditomines. These larvae all possess shorter and wider mandibles, enlarged heads and occassionally multiple teeth on the terebra. In the c-shaped harpalines, the entire body becomes physogastric, i.e., swollen as in scarabeoid larvae, the cerci are rudimentary and, in some cases, their food supply depends on the capacity of adults to accumulate seeds in subterranean nests (Ditomus, Dixus; see Brandmayr \& Zetto Brandmayr, 1987). In the laboratory, such larvae prove to be omnivorous, spermophagous or carnivorous (Brandmayr Zetto \& Brandmayr, 1975; Zetto Brandmayr, 1976; Luff, 1980; Bertrandi \& Zetto Brandmayr, 1991; Jørgensen \& Toft, 1997a, b; Saska \& Jarošík, 2001; Saska \& Honek, 2003). To date, true granivory in larvae is restricted to the "ophonoid" line of Harpalus, which have a characteristic larval morphology (Brandmayr et al., 1980). This line includes all species of Ophonus s. 1. that are associated with Umbelliferae and the Mediterranean-Afroindian subgenus Cryptophonus. A comparative laboratory study of the larval stages of several Harpaline species has confirmed the existence of two categories of phytophagous carabids. The former is able to develop on a mixed diet (seeds, insects or meat) such as Harpalus s. str. and its subgenus Harpalophonus. The latter, including all the species of Ophonus s. str. and most of the Metophonus, feed exclusively on seeds (Zetto-Brandmayr, 1990). Moreover, the larvae of Amara eurynota, A. similata and A. ovata often require seeds of a particular species of plant for successful development (Saska \& Jarošík, 2001; Saska, 2004), or they may require animal food (Saska, 2005). In the field, larvae of seed predators are occasionally observed feeding on seeds scattered on the soil surface or caching seeds in burrows (Kirk, 1972; Brandmayr Zetto \& Brandmayr, 1975; Alcock, 1976; Luff, 1980).

This review aims to outline the extent of the knowledge on the seed eating ground beetles of Italy. Data for other European countries (except the Czech Republic) are scarce. All the experimental data on carabid species belonging to the Italian fauna were compared and updated using: (1) graduate theses produced during the past 25 years at the University of Calabria; (2) data on Italian species kept in the Zoocoenoses laboratory (DiBEST, University of Calabria) and used in rearing experiments or in "cafeteria" tests accumulated over about 35 years and (3) gut dissections performed on rare species found during field trips. In this study we redefine the concept of phytophagous by using the terms carnivorous, omnivorous and granivorous. The term seed feeder refers to range of feeding adaptations from omnivory to true granivory. Moreover, we estimate the number of species of seed feeders and higher taxa present in Italy, and their relationship between plant seasonality and their reproduction rhythm. The taxonomic arrangement of all the data presented follows the updated version of the family Carabidae in the Fauna Europaea by Vigna Taglianti (http://www.fauna-eu.org).

\section{FOOD PREFERENCE}

Several aspects of seed consumption are poorly understood, including the preferences of particular species of carabid for specific species of seed. Many species of granivorous carabids climb plant stems and feed on the ripening seeds of grasses, umbelliferous, composite and cruciferous plants (Thiele, 1977; Hůrka, 1996; Martinkova et al., 2006). However, many less specialized carabids forage for seed mainly on the ground ("post-dispersal" seed predation, Honek et al., 2003; Mauchline et al., 2005). Some species of Amara prefer crucifer seeds and some Harpalus prefer seeds of composites (Lindroth, 1949; Thiele, 1977). Honek et al. (2007) studied the seed preferences of the adults of 30 species of carabids using the seeds of 28 common species of agricultural weeds in controlled laboratory experiments. The factors determining the preferences of carabids for particular species of seed are similar to that determining prey specificity in other predator groups. Body size of both predator and seed ("prey") are also important, probably because of the problems associated with handling seed of different sizes (Honek et al., 2003). It is also well known that primarily carnivorous insects utilize plant material as a food source in some phases of their development (Norris \& Kogan, 2000). Many species (Zabrini and Harpalini) are mainly granivorous as adults (Thiele, 1977; Zetto Brandmayr, 1990) and carnivorous species often supplement their diet of insects with seeds (Lund \& Turpin, 1977; Hurst \& Doberski, 2003, Fawki \& Toft, 2005).

The definition of phytophagy in carabids is not unequivocal. Lundgren (2009) considers feeding on "non-prey food" or feeding vegetable material in the gut as seed predation. However, "true" seed feeders are easily recognizable by their unmistakable morphological characters: large or at least a broad head, short and stout mandibles (Forbes, 1883; Zhavoronkova, 1969; Forsythe, 1982; Acorn \& Ball, 1991), shorter terebral length, wider incisor tip and larger molar width (Evans, 1965; Forsythe, 1982; Evans \& Forsythe, 1985; Frank, 2007).

Most carabids that feed on seeds belong to the tribes Harpalini (e.g. Harpalus, Ophonus, Pseudophonus) and Zabrini (Amara, Zabrus) (Zetto Brandmayr, 1990), with a few belonging to the Trechini, Platynini and Pterostichini (Goldschmidt \& Toft, 1997; Honek et al., 2003) (Appendix 1). Exceptions include the Scaritine, Clivina fossor, a single Trechine species, Trechus quadristriatus, scattered taxa in the Pterostichinae, such as Molopina (Abax parallelepipe$d u s$ ), Poecilina (Poecilus cupreus), Pterostichina (Pterostichus melanarius) and some Platyninae (Calathus fuscipes and Agonum mülleri) (Johnson \& Cameron, 1969; Larochelle, 1990; Goldscmidt \& Toft, 1997; Honek \& Martinkova, 2001; Toft \& Bilde, 2002; Honek et al., 2003, 2007, 2009; Mauchline et al., 2005; Saska et al., 2008; Lundgren et al., 2009). The latter two species are often "reluctant" to accept seeds in no choice experiments (Honek et al., 2003) or accept the soft seeds of Capsella bursa pastoris in large quantities (Calathus ambiguus, T. quadristriatus). In Abax parallelepipedus, phytophagous behaviour is recorded, 


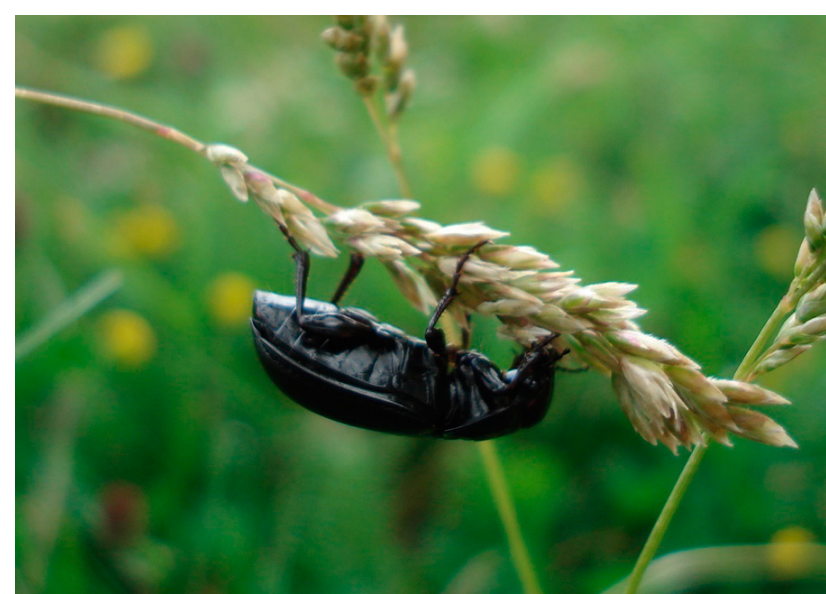

Fig. 1. A female of Zabrus costae Heyden, 1891, feeding on Poa bulbosa. Matese Mts, Molise, Southern Italy, June 14, 2007.

e.g. attacks on germinating seeds included under the well documented "non-prey food consumption" investigated by Lundgren (2009). All other cases studied belong to the phylogenetically easily identified Zabrini and Harpalinae (tribe Harpalini of other authors). Within these two taxa, we have distinguished four different feeding strategies (for a complete list of references view Appendix 1).

(1) Omnivorous (carnivorous + partly granivorous) species: most Harpalus s.l., Pseudoophonus, Anisodactylus, Scybalicus, Trichotichnus, Parophonus, Bradycellus, Acupalpus?, Amara (most species), Zabrus (Fig. 1), Acinopus and Daptus. The species in this feeding group are in the laboratory either predatory or zoophagous and eat a large spectrum of different kinds of seeds. A number of at least partly granivorous species of carabid specialize on weeds and are common in intensively managed agricultural landscapes (Saska et al., 2014; Kulkarni et al., 2015).

(2) Plant specialist omnivorous, i.e. partially carnivorous, but highly specialized in feeding on the seeds of just one plant genus; such as Tetraplatypus ganglbaueri, which feeds only on Satureja seeds or T. ruficollis, which only feeds on Calluna seeds. Tetraplatypus ganglbaueri occurs only in calcareous grasslands on Dinaric Karst, from Trieste to southern Dalmatia, where Satureja bushes form dense mats, similar to those of Calluna or Erica in heathland. It feeds on seeds both on the ground and on plants, by opening the flower calyx laterally (Zetto Brandmayr \& Brandmayr, 1978a). Tetraplatypus ruficollis possibly feeds in the same way on Calluna heaths.

(3) Imaginal omnivorous. Carabids that are omnivorous as adults but the larvae are strictly granivorous: Amara aulica and perhaps some other species/subgenera of Amara.

(4) True granivorous species: all Ophonus subgenera, Cryptophonus, all Ditomina so far tested, such as Ditomus, Dixus and Carterus. This category is easy to determine in the laboratory because meat is always refused. The only exception is Ophonus azureus, which sometimes accepts small pieces of beef. In this group, hyper specializations are known, such as the storing of seed in paedotrophic nests (brood care) by Ditomus calydonius (Fig. 2) and Dixus clypeatus. Many taxa restrict their choice of food to one or few

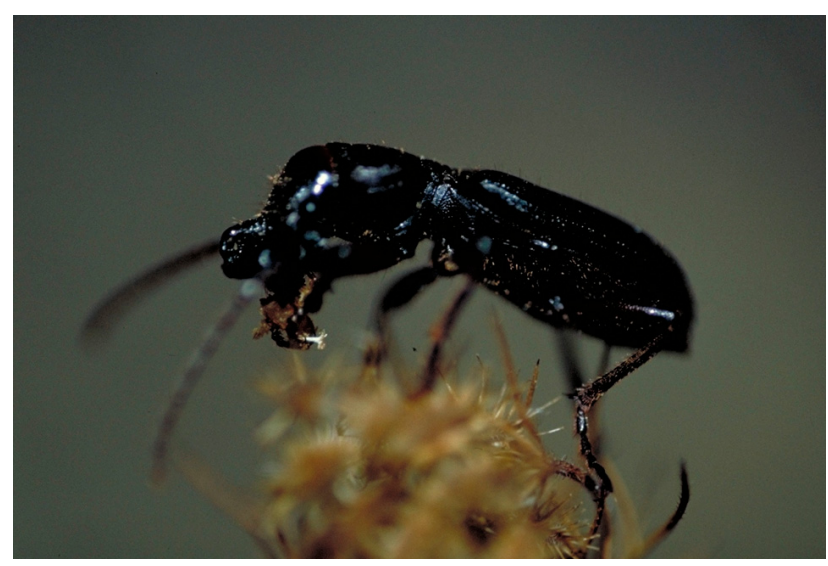

Fig. 2. A male of Ditomus calydonius (P. Rossi, 1790) feeding around midnight on Daucus carota umbels. The forelegs are holding a carrot fruit. Abandoned cropland in Calabria, Rende, June 1992.

plant genera. Carterus Dejean \& Boisduval specialises on the seed of umbellifers, Ditomus Bonelli (Sabienus Gozis,) on those of Daucus carota or D. gingidium (Brandmayr, 1974; Brandmayr \& Zetto Brandmayr, 1974, 1987; Larochelle, 1990; Brandmayr et al., 1994; Zetto Brandmayr et al., 1994) and Dixus clypeatus Rossi (Ditomus auctt.) on plantain seeds (Schremmer, 1960). In this the last group of species, a "main nursing plant" is often easily identifiable, as recorded for O. ardosiacus by Zetto Brandmayr (1983), or for Ditomus and Dixus.

\section{SEED FEEDING CARABIDS IN ITALY}

Vigna Taglianti (2005) records 1313 species of carabids in the Italian fauna and among these $243(18.50 \%)$ are seed feeders. This includes all the Zabrine and Harpaline taxa and the tentative inclusion of Amblystomina (seven species belonging to the genus Amblystomus), for which there is currently no data on food choice. Only 55 (4.2\%) of these can be considered to be true granivores and the inclusion of Graniger and Oedesis is tentative due to the current lack of data on their food preferences (Fig. 3).

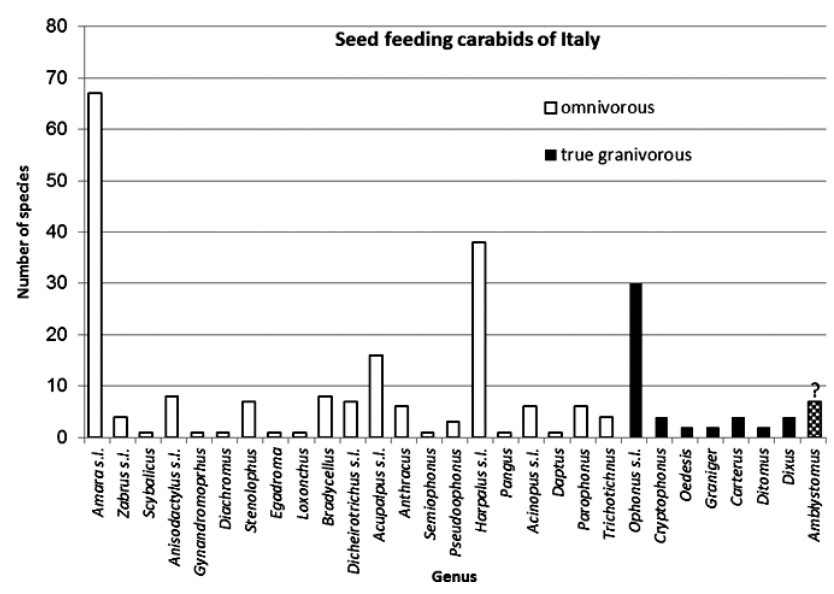

Fig. 3. The genera to which the 243 seed feeding species of carabids recorded in Italy belong. Black columns are the strictly granivorous taxa, the feeding habits of the Amblystomines are still unknown. 


\section{PLANT SEASONALITY AND REPRODUCTION RHYTHM}

Even though the importance of ground beetles as seed feeders is recognized (Luff, 1987; Kromp, 1999; Tooley \& Brust, 2002; Mauchline et al., 2005), little is known about the omnivorous/granivorous taxa in other European countries, such as Spain, Greece and Southern Russia. In Central and Western Europe, ground beetles are the most important invertebrates that feed on the seeds of herbaceous plants (Honek et al., 2003; Martinkova et al., 2006). The granivorous species typical of arable land belong mainly to the tribes Harpalini (e.g., the genera Anisodactylus, Har- palus, Parophonus, Pseudoophonus and Stenolophus) and Zabrini (Amara, Zabrus) (Lindroth, 1949; Thiele, 1977; Hůrka, 1996). In northern temperate agricultural areas some studies report seasonal fluctuations in the intensity of predation of weed seeds by carabid beetles (Tooley \& Brust, 2002; Honek et al., 2003; Saska et al., 2010). This variation, however, cannot always be attributed to changes in the activity/density of these predators (Honek et al., 2003; Mauchline et al., 2005; Saska et al., 2010). This incongruence may be attributed to intrinsic seasonal variation in consumption (Honek et al., 2006), but temperature variation may also contribute to the seasonal variation in

Table 1. Number of species, habitat, diet, main nursing plant, reproduction rhythm and possible phenological coincidence of all the genera (subgenera) of Italian seed feeding ground beetles. OL - open land; SUMMER - reproduction in spring or summer, with summer larvae; WINTER - reproduction in autumn or late autumn with winter larvae; BIENNIAL - species that have a two year life cycle. * - Hesperophonus azureus in the laboratory will also eat small pieces of meat.

\begin{tabular}{|c|c|c|c|c|c|c|}
\hline $\begin{array}{l}\text { Genus } \\
\text { (subgenus) }\end{array}$ & $\mathrm{Sp} \mathrm{N}$ & Habitat & Diet & $\begin{array}{l}\text { Main nursing } \\
\text { plant }\end{array}$ & $\begin{array}{l}\text { Reproduction } \\
\text { rhythm }\end{array}$ & $\begin{array}{l}\text { Phenological } \\
\text { coincidence }\end{array}$ \\
\hline Amara s. str. & 9 & OL, open forest & OMN & $\begin{array}{l}\text { No, except } \\
\text { for the association between } \\
\text { A. montivaga and T. officinalis }\end{array}$ & SUMMER & \\
\hline Zezea & 2 & OL, river gravels & OMN & No & SUMMER & \\
\hline Bradytus & 2 & OL & OMN & No & WINTER & \\
\hline Percosia & 2 & OL & OMN & No & WINTER & \\
\hline Curtonotus & 2 & $\mathrm{OL}$ & OMN & No & WINTER & \\
\hline Celia & 6 & $\begin{array}{l}\text { OL, abandoned } \\
\text { fields, heaths }\end{array}$ & OMN & $\begin{array}{c}\text { Artemisia? } \\
\text { Polygonum aviculare? }\end{array}$ & $\begin{array}{l}\text { WINTER: } 4 \\
\text { SUMMER: } 2\end{array}$ & \\
\hline Leiromorpha & 1 & Alpine OL & OMN & No & WINTER & \\
\hline Zabrus & 2 & OL, pasture & OMN & No & WINTER & \\
\hline Anisodactylus & 3 & Wetlands & OMN & No & SUMMER & \\
\hline Scybalicus & 1 & OL, clay soils & OMN & No & WINTER & \\
\hline Bradycellus & 2 & OL, meadows & OMN & No & WINTER & \\
\hline Tetraplatypus & 2 & OL, heaths & OMN & Satureja, Calluna & WINTER & YES \\
\hline Acupalpus & 2 & Wetlands & OMN & No & SUMMER & \\
\hline Pseudophonus & 2 & $\begin{array}{l}\text { OL, crops, } \\
\text { riparian forests }\end{array}$ & OMN & No & WINTER & \\
\hline Harpalus s. str. & 14 & OL, crops, pastures & OMN & No & SUMMER & \\
\hline Semiophonus & 1 & OL, sandy soils & OMN & No & SUMMER & \\
\hline Harpalophonus & 1 & OL, clay soils & OMN & No & SUMMER & \\
\hline Acinopus s. str. & 1 & OL, pastures & OMN & No & WINTER & \\
\hline Osimus & 1 & OL, pastures & OMN? & $\begin{array}{l}\text { Medicago minima? } \\
\text { Other plant species? }\end{array}$ & WINTER & YES \\
\hline Daptus & 1 & Salt marshes & OMN & No & SUMMER & \\
\hline Trichotichnus & 1 & Forests & OMN & No & BIENNIAL & \\
\hline Parophonus & 2 & OL, croplands & OMN & No & SUMMER & \\
\hline Ophonus s. str. & 4 & OL, aband. fields & GRAN & Daucus carota & WINTER & YES \\
\hline Hesperophonus & 1 & $\begin{array}{l}\text { OL, pastures, } \\
\text { cropland }\end{array}$ & GRAN* & Daucus, other & $\begin{array}{l}\text { WINTER, som. } \\
\text { SUMMER }\end{array}$ & YES \\
\hline Metophonus & 5 & OL, pastures & GRAN & Daucus & WINTER & YES \\
\hline Incisophonus & 1 & OL, pastures & GRAN & Foeniculum & WINTER & YES \\
\hline Cryptophonus & 1 & OL, cropland & GRAN & Daucus, Foeniculum & WINTER & YES \\
\hline Ditomus (Sabienus) & 2 & OL, garigues & GRAN & D. gingidium, $D$. carota & SUMMER & YES, brood care in summer \\
\hline Dixus & 2 & OL, garigues & GRAN & Plantago spp. & SUMMER & YES, brood care in summer \\
\hline Tschitscherinellus & 1 & OL, aband. fields & GRAN & D. gingidium, D. carota & SUMMER & $\begin{array}{c}\text { YES, presumably brood } \\
\text { care in summer }\end{array}$ \\
\hline Carterus & 2 & $\begin{array}{l}\text { OL, aband. fields and } \\
\text { umbel plant seed crops }\end{array}$ & GRAN & $\begin{array}{c}\text { Daucus spp., anise } \\
\text { and celery seed crops }\end{array}$ & SUMMER & $\begin{array}{l}\text { YES, presumably brood } \\
\text { care in summer }\end{array}$ \\
\hline
\end{tabular}


the amount of seed predation by carabid beetles. To obtain a better insight into the factors influencing the reproduction rhythm of granivorous carabids in Italy, a table (Table 1) was constructed, which contains data on habitat and, if available, "main nursing plant". With reference to the omnivorous genera/subgenera, reproduction may occur in spring (summer larvae) or autumn (winter larvae); Amara montivaga is defined as a "dandelion specialist" (Honek et al., 2005) because this species aggregates in stands dominated by Taraxacum officinale. Zabrus species are autumn breeders, feeding on a wide range of graminaceous plants. In the omnivorous Anisodactylines, the breeding season depends more on soil moisture, with xerophilic taxa (Scybalicus) reproducing in autumn and the more hygrophilic Anisodactylus in spring/late spring. In the Stenolophini, we know of a xerophilic genus with winter larvae (Bradycel$l u s$ ) and a hygrophilic taxon (Acupalpus) with summer larvae. In the xerophilous Tetraplatypus ganglbaueri and $T$. ruficollis, carnivory is associated with strictly specialized seed feeding. They are associated with autumn disseminating plants, such as Satureja and Calluna (Zetto Brandmayr \& Brandmayr, 1978a), which seems to account for their phenological coincidence. In the taxa around Harpalus, the larvae of some lineages (Harpalus s. str., Harpalophonus, Semiophonus) occur in summer and others in winter (Pseudoophonus), depending mainly on climate or phylogenic constraints, as reported by Larsson (1939), Paarmann (1979) and Hůrka (1986) for Carabus, with no evident association with a particular nursing plant.

In granivorous taxa, a phenological coincidence with autumn ripening umbelliferous plants is widespread in the genus Ophonus (Zetto Brandmayr, 1983), but in some Ditomines (Ditomus, Dixus, Machozetus?) the evolution of brood care in paedotrophic nests enabled a shift to summer breeding (Sharova \& Makarov, 1983; Brandmayr \& Zetto Brandmayr, 1987). Thus, different granivorous taxa have different adaptive strategies associated with the same nursing plant. In contrast, the free-living winter larvae of Ophonus are "post-dispersal seed predators", whereas $D i$ tomus and probably Carterus and Dixus care for their summer larvae by feeding them with Daucus carota or Plantago seeds. The associations between plant seasonality and reproduction rhythm of granivorous carabids are in need of further research.

\section{DISCUSSION}

The findings of this study indicate that it would be appropriate to rearrange the three feeding guilds of Forbes (1883) and Zhavoronkova (1969) in the following way:

(1) carnivorous, species with long mandibles and predaceous larvae, that are sometimes also dependent on nonprey food. There are a wide variety of morphotypes of larvae in this category of species (Zetto Brandmayr et al., 1998): soil pore walkers, surface runners, surface walkers, sand diggers, parasitoids, etc. Many taxa show a more or less pronounced prey specialization (Thiele, 1977), which is not discussed here;
(2) omnivorous species with stout mandibles, capable of crushing hard seeds and with larvae that are of a seed-eating morphotype ("spermophagous"), with wide mandibles and terebra often with supernumerary teeth. All Zabrines and most Harpalines belong to this category, including the subtribes Anisodactylines and Selenophorines;

(3) granivorous species, found only in some of the Harpalines (Ophonus, Ditomina), all the larvae of which have strongly enlarged heads, short mandibles and some genera have a characteristic c-shaped scarabeoid larva. This last characteristic may be associated with the parent providing the larva with seeds.

The new categorization means that sensu stricto only the Zabrini and Harpalinae are seed feeders and that the few cases of seed feeding in other taxa are due to non-prey food intake (Lundgren, 2009).

Considering all the carabids characterized as seed feeders, we identified four levels of granivory: omnivorous (carnivorous + partly granivorous); omnivorous, but highly specialized in feeding on the seeds of just one plant genus; imaginal omnivorous and true granivorous species.

Moreover, there is a large body of evidence that seed feeding also occurs in the tropics, where many phylogenetically ancient harpaline stocks (Notiobia, Trichotichnus, Platymetopus) are known to be both carnivorous and small seed predators of several tree fruits: Ficus, Bellucia, Loreya, Miconia (Paarmann et al., 2001, 2002, 2003, 2006).

Within the omnivorous taxa, there are some interesting variations. Despite their predatory habits, both on seeds and animal food, some species may specialize on a restricted group (genus) of plants, which may influence their choice of habitat (Tetraplatypus ganglbaueri, T. ruficollis). In some species, such as Amara montivaga, an evident preference for species-specific seeds is recorded, (Honek et al., 2005) which is not congruent with their choice of habitat. Finally, some species may be omnivorous in the adult stage but more dependent on seeds during the larval stages (Saska, 2005). According to our data, the provision of fresh meat in cafeteria or no-choice experiments should be used as a preliminary test to distinguish omnivorous from granivorous taxa.

The number of species that can be classified as seed feeders in the Italian fauna is 243 out of a total of 1313 $(18.5 \%), 55$ of which $(4.2 \%)$ are true granivores. On the Iberian Peninsula, a total of 1255 carabid species are recorded (Serrano, 2003, 2013), of which $276(22 \%)$ are seed feeders and $57(4.5 \%)$ are true granivores. In continental countries, e.g. in Central Europe (Koch, 1989), there are $179(23.2 \%)$ seed feeders, and $21(2.7 \%)$ true granivores out of a total of 770 species. In Russia and adjacent countries (Krizhanowskij et al., 1995), 630 taxa of seed feeders occur $(20.5 \%)$, of which $79(2.6 \%)$ are true granivores out of a total of 3075 species. In Fennoscandia (Lindroth, $1945,1985-1986)$ there are $73(18.1 \%)$ seed feeders and 7 $(1.7 \%)$ true granivores out of a total of 403 species. Summing up, in Western Palearctic countries the percentage of seed feeders varies from 18 to $23 \%$, and constitutes an important component of the faunas. The percentage of true 
granivores ranges from 1.7 to $4.4 \%$, and they occur mainly in Mediterranean countries, such as Spain and Italy.

When the granivorous carabids breed is known only for a small fraction of the European fauna and very little is known about those in the Mediterranean area. For omnivorous carabids, when they breed depends mainly on climate and habitat factors (e.g. wet versus dry soil), and "phenological coincidence" is frequently recorded between breeding in granivorous species and seed production of a "main nursing plant". The reproductive rhythms of the Ditomines are exceptional, and currently summer reproduction in paedotrophic nests is only suggested for several genera living within and outside Europe.

In the last two decades seed-feeding carabids have been re-evaluated in terms of ecosystem services in the agricultural environment, as potential auxiliary agents for weed control in sustainable cropland management (Honek et al., 2003, 2005; Westerman et al., 2003; Mauchline et al., 2005; Jacob et al., 2006; Gaines \& Gratton, 2010; Kulkarni et al., 2015). Nevertheless, the precise species traits and habitat associations of this feeding guild are poorly known, especially in southern European countries. Further research on this topic should also take into account changing scenarios driven by global warming, particularly as there have been recent reports of mass occurrences of Ditomines (Carterus) in carrot, anise and celery seed crops (Koçak et al., 2007; Fabbri \& Contarini, 2009). This clearly shows us that the ecology of seed-feeding carabids in Mediterranean countries is still poorly investigated and that some species that are considered harmless today could become the "pests" of tomorrow.

ACKNOWLEDGEMENTS. The authors are indebted to A. Mazzei and M. Sapia who helped with the sampling of carabid beetles in various kinds of habitats, and S. Venn for editing the English. Two anonymous reviewers greatly improved the text and contents of this paper.

\section{REFERENCES}

ACORN J.H. \& BALL G.E. 1991: The mandibles of some adult ground beetles: Structure, function, and the evolution of herbivory (Coleoptera: Carabidae). — Can. J. Zool. 69: 638-650.

Alcock J. 1976: The behaviour of the seed-collecting larvae of a carabid beetle (Coleoptera). - J. Nat. Hist. 10: 367-375.

AlEssi R. 1995: Regolazione esogena dello sviluppo preimmaginale di Ophonus sabulicola (Panzer) 1796 (Coleoptera: Carabidae) in dipendenza da temperature e fotoperiodo. Thesis, University of Calabria, $68 \mathrm{pp}$. [in Italian].

BARBIERI R. 1998: Strategie alimentary e adattamenti morfofunzionali in Acinopus picipes (Coleoptera, Carabidae, Harpalini). Thesis, University of Calabria, 93 pp. [in Italian].

Bertrandi F. \& Zetto Brandmayr T. 1991: Osservazioni sulla dieta e cenni sulla bionomia del genere Harpalus Latreille (Coleoptera, Carabidae). - Ber. Nat. Med. Verein Innsbruck 78: $145-155$.

Brandmayr P. 1972: Studio ecologico sui Coleotteri Carabidi di due formazioni vegetali dell'Istria montana. - Boll. Zool. 39: 523-529.

Brandmayr P. 1974: Le cure parentali di Carterus (Sabienus) calydonius Rossi (Coleoptera: Carabidae). - Atti Accad. Sci. Torino 108: 811-818.
Brandmayr P. \& ZetTo Brandmayr T. 1974: Sulle cure parentali e su altri aspetti della biologia di Carterus (Sabienus) calydonius Rossi, con alcune considerazioni sui fenomeni di cura della prole sino ad oggi riscontrati in Carabidi (Coleoptera, Carabidae). - Redia 55: 143-175.

Brandmayr P. \& Zetto Brandmayr T. 1980: "Life forms" in imaginal Carabidae (Coleoptera): a morphofunctional and behavioural synthesis. — Monit. Zool. Ital. (N.S.) 14: 97-99.

BrandmaYr P. \& Zetto BrandmaYr T. 1982: Identificazione delle larve del genere Ophonus Dejean, 1821 (sensu novo) e note bionomiche (Coleoptera, Carabidae). - Mem. Soc. Entomol. Ital. 60: 67-103.

Brandmayr P. \& Zetto Brandmayr T. 1987: The problem of presocial behaviour in Ditomine ground beetles. - Publ. Ist. Entomol. Univ. Pavia 36: 15-18.

Brandmayr P., Ferrero E. \& Zetto Brandmayr T. 1980: Larval versus imaginal taxonomy and the systematic status of the ground beetle taxa Harpalus and Ophonus (Coleoptera: Carabidae: Harpalini). — Entomol. Gener. 6: 335-353.

Brandmayr P., Brunello Zanitti C. \& Zetto Brandmayr T. 1981: Frequency of the main life forms of imaginal Carabidae (Coleoptera) in communities of some environments of different vegetation and soil type. - Monit. Zool. Ital. (N.S.) 15: 303-304.

Brandmayr P., Pizzolotto R. \& Zetto Brandmayr T. 1990: The spermophagy in Carabid beetles. - Ethol. Ecol. Evol. 2: 299300.

Brandmayr P., Pizzolotto R. \& Zetto Brandmayr T. 1994: Population biology and nesting of Carterus calydonius Rossi (Colepotera, Carabidae, Ditomini). — Boll. Zool. (Suppl.) 61: $50-51$.

Brandmayr P., Mingozzi T., Scalercio S., Passalacqua N., Rotondaro F. \& Pizzolotto R. 2002: Stipa austroitalica garigues and mountain pastureland in the Pollino National Park (Calabria, Southern Italy). In Redecker B., Härdtle W., Finck P., Riecken U. \& Schröder E. (eds): Pasture Landscapes and Nature Conservation. Springer, Berlin, Heidelberg, pp. 53-66.

Brandmayr Zetto T. \& Brandmayr P. 1975: Biologia di Ophonus puncticeps Steph. Cenni sulla fitofagia delle larve e loro etologia (Coleoptera, Carabidae). - Ann. Fac. Sci. Agr. Univ. Torino 9: 421-430.

Briggs J.B. 1965: Biology of some ground beetles (Col., Carabidae) injurious to strawberries. - Bull. Entomol. Res. London 56: 79-93.

Burakowsky B. 1967: Biology, ecology and distribution of Amara pseudocommunis Burak. (Coleoptera: Carabidae). Ann. Zool. 24: 486-523.

BurmeIster F. 1939: Biologie, Ökologie und Verbreitung der Europäischen Käfer. I. Band: Adephaga, Caraboidea. H. Goeke, Krefeld, 307 pp.

DAVIES M.J. 1953: The contents of the crops of some British carabid beetles. - Entomol. Month. Mag. 88: 18-23.

Dawson N. 1965: A comparative study of ecology of eight species of fenland Carabidae (Coleoptera). - J. Anim. Ecol. 34: 299-314.

Evans M.E.G. 1965: A comparative account of the feeding methods of the beetles Nebria brevicollis (F.) (Carabidae) and Philonthus decorus (Grav.) (Staphylinidae). - Trans. R. Soc. Edinburgh 66: 91-109.

Evans M.E.G. \& Forsythe T.G. 1985: Feeding mechanisms, and their variation in form, of some adult ground-beetles (Coleoptera: Caraboidea). - Acta Entomol. Sin. 206: 113-143.

FABBRI R. \& CONTARINI E. 2009: Pullulazioni in campi di ombrellifere da seme del coleottero carabide Carterus fulvipes (La- 
treille, 1817) (Insecta, Coleoptera, Carabidae). — Quad. Stud. Not. Stor. Nat. Rom. 29: 203-211.

FaWki S. \& ToFt S. 2005: Food preferences and the value of animal food for the carabid beetle Amara similata (Gyll.) (Col., Carabidae). - J. Appl. Entomol. 129: 551-556.

Forbes S.A. 1883: The food relationships of the Carabidae and Coccinellidae. - Illinois St. Lab. Nat. Hist. Bull. 1: 33-64.

Forsythe T.G. 1982: Feeding mechanisms of certain ground beetles (Coleoptera: Carabidae). - Coleopt. Bull. 36: 26-73.

Frank S.D. 2007: Consequences of Omnivory and Alternative Food Resources on the Strength of Trophic Cascades. PhD Thesis, University of Maryland, $178 \mathrm{pp}$.

Gaines H.R. \& Gratton C. 2010: Seed predation increases with ground beetle diversity in a Wisconsin (USA) potato agroecosystem. - Agric. Ecosyst. Environ. 137: 329-336.

Giglio A., Brandmayr P., Ferrero E.A., Giulianini P.G., Perrotta E., Talarico F.F. \& Zetto Brandmayr T. 2008: Ultrastructure of the antennal sensorial appendage of larvae of Ophonus ardosiacus (Lutshnik, 1922) (Coleoptera, Carabidae) and possible correlations between size and shape and the larval feeding habits. - Zool. Anz. 247: 202-221.

Goldschmidt H. \& ToFt S. 1997: Variable degrees of granivory and phytophagy in insectivorous carabid beetles. - Pedobiologia 41: 521-525.

Hengeveld R. 1980a: Qualitative and quantitative aspects of the food of ground beetles (Coleoptera, Carabidae): a review. Neth. J. Zool. 30: 555-563.

Hengeveld R. 1980b: Polyphagy, oligophagy and food specialization in ground beetles (Coleoptera: Carabidae). - Neth. $J$. Zool. 30: 564-584.

HeNGeVeld R. 1980c: Food specialization in ground beetles: an ecological or a phylogenetic process? (Coleoptera, Carabidae). — Neth. J. Zool. 30: 585-594.

HENGEVELD R. 1981: The evolutionary relevance of feeding habits of ground beetles (Coleoptera, Carabidae). - Entomol. Scand. (Suppl.) 15: 305-315.

Holland J.M. \& LufF M.L. 2000: The effects of agricultural practices on Carabidae in temperate ecosystems. - Integr. Pest Manag. Rev. 5: 109-129.

HoneK A. \& Martinkova Z. 2001: Aggregation of ground beetles (Carabidae, Coleoptera) on winter rape seeds dispersed on the ground. - Plant Prot. Sci. 37: 97-102.

Honek A., Martinkova Z. \& Jarosik V. 2003: Ground beetles (Carabidae) as seed predators. - Eur. J. Entomol. 100: 531544.

Honek A., Martinkova Z. \& SASKa P. 2005: Post-dispersal predation of Taraxacum officinale (dandelion) seed. - J. Ecol. 93: 345-352.

Honek A., SASKa P. \& Martinkova Z. 2006: Seasonal variation in seed predation by adult carabid beetles. - Entomol. Exp. Appl. 118: $157-162$.

Honek A., Martinkova Z., Saska P. \& Pekar S. 2007: Size and taxonomic constraints determine the seed preferences of Carabidae (Coleoptera). - Basic Appl. Ecol. 8: 343-353.

Honek A., Martinkova Z., Saska P. \& Koprdova S. 2009: Role of post-dispersal seed and seedling predation in establishment of dandelion (Taraxacum agg.) plants. - Agric. Ecosyst. Environ. 134: 126-135.

HŮRKA K. 1986: The Developmental type of Carabidae in the temperate zones as a taxonomic character. In den Boer P.J., Luff M.J., Mossakowski D. \& Weber F. (eds): Carabid Beetles, their Adaptations and Dinamics. Proc. XVII Int. Congress of Entomology, Hamburg, 1984. G. Fischer, Stuttgart, New York, pp. 187-193.
HƯRKA K. 1992: The taxonomic status of Semiophonus (Col., Carabidae, Harpalini) and the description of the larva of Harpalus (Semiophonus) signaticornis. - Acta Entomol. Bohemoslov. 89: 29-34.

HưRKA K. 1996: Carabidae of the Czech and Slovak Republics. Kabourek, Zlín, 565 pp.

HŮRKA K. 1998: Larval taxonomy, development and diet of Amara (A.) famelica, A. (A.) littorea and A. (A.) proxima (Coleoptera: Carabidae: Amarinae). - Acta Soc. Zool. Bohemoslov. 62: 105-113.

HŮRKA K. \& JAROŠíK V. 2001: Development, breeding type and diet of members of the Amara communis species aggregate (Coleoptera: Carabidae). - Acta Soc. Zool. Bohemoslov. 65: $17-23$.

HŮRKA K. \& JAROŠí V. 2003: Larval omnivory in Amara aenea (Coleoptera: Carabidae). — Eur. J. Entomol. 100: 329-335.

HuRST C. \& Doberski J. 2003: Wild flower seed predation by Pterostichus madidus (Carabidae: Coleoptera). — Ann. Appl. Biol. 142: 251-254.

Jacob H.S., Minkey D.M., Gallagher R.S. \& Borger C.P. 2006: Variation in postdispersal weed seed predation in a crop field. Weed Sci. 54: 148-155.

Johnson N.E. \& CAMERon R.S. 1969: Phytophagous ground beetles. - Ann. Entomol. Soc. Am. 62: 909-914.

JørGENSEN H.B. \& Toft S. 1997a: Role of granivory and insectivory in the life cycle of the carabid beetle Amara similata. - Ecol. Entomol. 22: 7-15.

JørGensEn H.B. \& Toft S. 1997b: Food preference, diet dependent fecundity and larval development in Harpalus rufipes (Coleoptera: Carabidae). — Pedobiologia 41: 307-315.

KIRK V.M. 1972: Seed-caching by larvae of two ground beetles, Harpalus pensylvanicus and H. erraticus. - Ann. Entomol. Soc. Am. 65: 1426-1428.

KLIMES P. \& SASKA P. 2010: Larval and adult seed consumption affected by the degree of food specialization in Amara (Coleoptera: Carabidae). — J. Appl. Entomol. 134: 659-666.

Koçak E., Kesdek M. \& Yildirim E. 2007: A new anise (Pimpinella anisum L.) pest: Carterus dama (Rossi, 1792) (Coleoptera: Carabidae). - S. Ü. Ziraat Fakültesi Derisi 21(42): 1-3.

Kосн K. 1989: Die Käfer Mitteleuropas, Ökologie Bd. 1. Goecke and Evers, Krefeld, pp. 15-107.

Kolesnikov F.N. \& Malueva E.V. 2015: Life history of Amara fulva (Coleoptera: Carabidae) in the southwest forest zone of the East European Plain. - Eur. J. Entomol. 112: 127-134.

Kryzhanovskij O.L., Belousov I.A., Kabak I.I., Kataev B.M., Makarov K.V. \& Shilenkov V.G. 1995: A Checklist of the Groundbeetles of Russia and Adjacent Lands (Insecta, Coleoptera, Carabidae). Pensoft, Sofia, Moscow, 271 pp.

KROMP B. 1999: Carabid beetles in sustainable agricolture: a review on pest control efficacy, cultivation impacts and enhancement. - Agric. Ecosyst. Environ. 74: 187-228.

Kulkarni S.S., Dosdall L.M. \& Willenborg C.J. 2015: The role of ground beetles (Coleoptera: Carabidae) in weed seed consumption: A review. - Weed Sci. 63: 335-376.

LAROCHELle A. 1990: The food of the carabid beetles (Coleoptera: Carabidae, including Cicindelinae). - Fabreries (Suppl.) 5: $1-132$.

LARSSON S.G. 1939: Entwicklungstypen und Entwicklungszeiten der dänischen Carabiden. - Entomol. Meddr. 20: 277-562.

LindRoth C.H. 1945: Die Fennoskandischen Carabidae I. Göteborgs Kungliga Vetenskaps- och Vitterhets-Samhälles Handlingar, Göteborg, 709 pp.

LindRoth C.H. 1949: Die Fennoskandischen Carabidae III. Göteborgs Kungliga Vetenskaps- och Vitterhets-Samhälles Handlingar, Göteborg, 911 pp. 
Lindroth C.H. 1985-1986: The Carabidae (Coleoptera) of Fennoscandia and Denmark. Fauna Entomologica Scandinavica. Vol. 15, Part I, II. Scandinavian Science Press, Leiden, 497 pp.

LÖVEI G.L. \& SunDERLAND K.D. 1996: Ecology and behaviour of ground beetles (Coleoptera: Carabidae). - Annu. Rev. Entomol. 41: 231-256.

LufF M.L. 1980: The biology of the ground beetle Harpalus rufipes in a strawberry field in Northumberland. - Ann. Appl. Biol. 94: 153-164.

LuFF M.L. 1987: Biology of polyphagous ground beetles in agriculture. - Agric. Zool. Rev. 2: 237-278.

LunD R.D. \& TURPIN F.T. 1977: Carabid damage to weed seeds found in Indiana cornfields. - Environ. Entomol. 6: 695-698.

LundGren G.J. 2009: Relationship of Natural Enemies and Nonprey Foods. Springer, Dordrecht, 453 pp.

Manley G.V. 1971: A seed-caching carabid (Coleoptera). — Ann. Entomol. Soc. Am. 64: 1474-1475.

Martinkova Z., SASKa P. \& HoneK A. 2006: Consumption of fresh and buried seed by ground beetles (Coleoptera: Carabidae). - Eur. J. Entomol. 103: 361-364.

Mauchline A.L., Watson S.J., Brown V.K. \& Froud-Williams R.J. 2005: Post-dispersal seed predation of non-target weeds in arable crops. - Weed Res. 45: 157-164.

Mazzei A., Bonacci T., Zetto T. \& Brandmayr P. 2010: La carabidofauna dell'ecotopo fluviale del Crati (Cosenza, Italia, (Coleoptera, Carabidae). - Naturalista Sicil. (S. IV) 34: 187-199.

Melber A. 1983: Calluna-Samen als Nahrungsquelle für Laufkäfer in einer nordwestdeutschen Sandheide (Col. Carabidae). —Zool. Jb. Syst. 110: 87-95.

NorRis R.F. \& Kogan M. 2000: Interactions between weeds, arthropod pests, and their natural enemies in managed ecosystems. - Weed Sci. 48: 94-158.

PAARMANN W. 1979: Ideas about the evolution of the various annual reproduction rhythms in carabid beetles of the different climatic zones. - Misc. Pap. LH Wageningen 18: 119-132.

Paarmann W., Adis J., Stork N.E., Gutzmann H., Stumpe P., Staritz B., Bolte H., Holzkamp K., Niers C. \& De Fonseca C. R.V. 2001: The structure of ground beetle assemblages (Coleoptera, Carabidae) at fig fruit falls (Moraceae) in a terra firme rain forest near Manaus (Brazil). - J. Trop. Ecol. 17: 549-561.

Paarmann W., Gutzmann H., Stumpe P., Bolte H., Küppers S.C., Adis J., Stork N.E. \& De Fonseca C.R.V. 2002: The structure of ground beetle assemblages (Coleoptera, Carabidae) at fruit falls of Melastomataceae trees in a Brazilian terra firme rain forest. - Biotropica 34: 368-375.

Paarmann W., Adis J., Stork N.E., Stumpe P., Gutzmann H. \& Holzkamp K. 2003: Finding the host tree species of Notiobia nebrioides Perty (Coleoptera, Carabidae), a member of theseed-feeding guild at fruit falls in the Amazonian non-inundated lowland rain forests. - J. Nat. Hist. 37: 839-844.

Paarmann W., Faust N., Arndt E., Lüchtrath I. \& Rohe W. 2006: Constant seed size and mandible growth - fundamental problem for granivorous ground beetle larvae (Coleoptera, Carabidae). - Entomol. Fenn. 17: 334-339.

Pizzolotto R. 1994: Ground beetles (Coleoptera, Carabidae) as a tool for environmental management: a geographical information system based on carabids and vegetation for the Karst near Trieste (Italy). In Desender K., Dufrêne M., Loreau M., Luff M.L. \& Maelfait J.-P. (eds): Carabid Beetles: Ecology and Evolution. Springer, Dordrecht, pp. 343-351.

Pizzolotto R. 2009: Characterization of different habitats on the basis of the species traits and eco-field approach. - Acta Oecol. 35: 142-148.

Pizzolotto R. \& Brandmayr P. 1990: The carabid grouping of the Nebrodi mountains in Sicily: ecological and historical indica- tors. Stork N.E. (ed.): The Role of Ground Beetles in Ecological and Environmental Studies. Intercept, Andover, pp. 201-207.

Pizzolotto R., Brandmayr P. \& Mazzei A. 2005: Carabid beetles in a Mediterranean Region: biogeographical and ecological features. - DIAS Report 114: 243-254.

Pizzolotto R., Mazzei A., Belfiore T., Bonacci T., Odoguardi R., Scalercio S., Iannotta N. \& Brandmayr P. 2009: Biodiversità dei Coleotteri Carabidi (Coleoptera: Carabidae) nell'agroecosistema oliveto in Calabria. - Entomologica: Ann. Entomol. Gener. Appl. 41: 5-11.

SASKA P. 2004: Carabid larvae as predators of weed seeds: granivory in larvae of Amara eurynota (Coleoptera: Carabidae). - Commun. Agric. Appl. Biol. Sci. 69: 27-33.

SASKA P. 2005: Contrary food requirements of the larvae of two Curtonotus (Coleoptera: Carabidae: Amara) species. - Ann. Appl. Biol. 147: 139-144.

SASKA P. 2008: Effect of diet on the fecundity of three carabid beetles. - Physiol. Entomol. 33: 188-192.

SAska P. \& Honek A. 2003: Temperature and development of central European species of Amara (Coleoptera: Carabidae). —Eur. J. Entomol. 100: 509-515.

SASKA P. \& JAROŠí V. 2001: Laboratory study of larval food requirements in nine species of Amara (Coleoptera: Carabidae). - Plant Prot. Sci. 37: 103-110.

Saska P., Van Der Werf W., De Vries E. \& Westerman P.R. 2008: Spatial and temporal patterns of carabid activity-density in cereals do not explain levels of predation on weed seeds. Bull. Entomol. Res. 98: 169-181.

Saska P., Martinkova Z. \& Honek A. 2010: Temperature and rate of seed consumption by ground beetles (Carabidae). - Biol. Contr. 52: 91-95.

Saska P., NĚMeČek J., Koprdová S., Skuhrovec J. \& Káš M. 2014: Weeds determine the composition of carabid assemblage in maize at a fine scale. - Sci. Agric. Bohem. 45: 85-92.

SCHREMMER F. 1960: Beitrag zur Biologie von Ditomus clypeatus Rossi, eines körnersammelnder Carabiden. — Z. Arbeitsgem. Österr. Entomol. 3: 140-146.

Serrano J. 2003: Catálogo de los Carabidae (Coleoptera) de la Península Ibérica. Monografías de la Sociedad Entomológica Aragonesa, Zaragoza, 130 pp.

Serrano M.J. 2013: New Catalogue of the Family Carabidae of the Iberian Peninsula (Coleoptera). Universidad de Murcia, $196 \mathrm{pp}$.

Sharova I.K. 1960: Morpho-ecological types of carabid larvae. - Zool. Zh. 39: 691-708 [in Russian].

Sharova I.K. \& MaKarov K.V. 1983: Larva of Machozetus lehmanni Men. (Coleoptera, Carabidae). — Entomol. Rev. 62: 78-83.

SkUHRAVY V. 1959: Die Nahrung der Feldcarabiden. - Acta Soc. Entomol. Czechoslov. 56: 1-18 [in Czech, Germ. abstr.].

Telfer M. 2010: The Wormwood Moonshiner Amara fusca. URL: http://www.markgtelfer.co.uk/2010/03/ (last access March 19, 2016).

Thiele H.U. 1977: Carabid Beetles in their Environments. Springer, Berlin, $369 \mathrm{pp}$.

Toft S. \& BILDE T. 2002: Carabid diet and food value. In Holland J.M. (ed.): The Agroecology of Carabid Beetles. Intercept, Andover, pp. 81-110.

Tooley J. \& BRust G.E. 2002: Weed seed predation by carabid beetels. In Holland J.M. (ed.): The Agroecology of Carabid Beetles. Intercept, Andover, pp. 215-229.

Vigna Taglianti A. 2005: Checklist e Corotipi delle specie di Carabidi della fauna Italiana. In Brandmayr P., Zetto T. \& Pizzolotto R. (eds): I Coleotteri Carabidi per la valutazione am- 
bientale e la conservazione della biodiversità. APAT, Roma, pp. 186-225.

Vigna Taglianti A. \& Audisio P. 2013: Fauna Europaea: Carabidae. Fauna Europaea Version 2.6.2. URL: http://www.faunaeur.org

Westerman P.R., Hofman A., Vet L.E.M. \& Van Der Werf W. 2003: Relative importance of vertebrates and invertebrates in epigeaic weed seed predation in organic cereal fields. - Agric. Ecosyst. Environ. 95: 417-425.

ZetTo Brandmayr T. 1976: Nutrizione e allevamento di Carabidi esclusivamente fitofagi: spermofagia larvale di Ophonus ardosiacus Lutsh. - Redia 59: 197-206.

Zetto Brandmayr T. 1978: Studi sulla fitofagia nei Carabidi: spermofagia larvale di Ophonus ardosiacus Lutsh. (Coleoptera, Carabidae). In: Proc. XI. Congr. Naz. Ital. Entomol., 10-15 May 1976, Portici, Sorrento. pp. 9-64.

Zetto Brandmayr T. 1980: Regolazione esogena dello sviluppo preimmaginale di Ophonus rotundicollis Fairm. et Lab. (ardosiacus Lutsh) (Coleoptera, Carabidae) in dipendenza da temperatura e fotoperiodo. In: Proc. XII. Congr. Naz. Ital. Entomol., Roma 1980. pp. 105-112.

Zetto Brandmayr T. 1983: Life cycle, control and propagation rhythm and fecundity of Ophonus rotundicollis Fairm. et Lab. (Coleoptera, Carabidae, Harpalini) as an adaptation to the main feeding plant Daucus carota L. (Umbelliferae). In Brandmayr P., Den Boer P.J. \& Weber F. (eds): Ecology of Carabids: The Synthesis of Field Study and Laboratory Experiment. Proc. 4th Symp. Carab. '81, Haus Rothenberge, Westphalia, September 24-26. Westphalia, Münster, pp. 93-103.
ZetTo BrandmaYr T. 1990: Spermophagous (seed-eating) ground beetles: first comparison of the diet and ecology of the harpaline genera Harpalus and Ophonus (Col., Carabidae). In Stork N. (ed.): The Role of Ground Beetles in Ecological and Environmental Studies. Intercept, Andover, pp. 307-316.

Zetto Brandmayr T. \& Brandmayr P. 1978a: Sur la biologie d'un carabique très interessant: Tetraplatypus ganglbaueri Apfb. Cordulia (Québec) 4: 156-158.

Zetto Brandmayr T. \& BRANDMAYR P. 1978b: Morfologia preimmaginale e note bionomiche di Harpalophonus circumpunctatus italus Schaum. (Col., Carabidae). - Boll. Ist. Entmol. Univ. Bologna 34: 65-74.

Zetto Brandmayr T., Puzzo F. \& Rocca E. 1994: Further observations on parental behaviour in Carterus (Sabienus) calydonius Rossi (Coleoptera, Carabidae). - Boll. Zool. (Suppl.) 61: 59-60.

Zetto Brandmayr T., Giglio A., Marano I. \& Brandmayr P. 1998: Morphofunctional and ecological features in carabid larvae: a contribution to distinguish between affinity and convergence. In: Proc. XX. International Congress of Entomology, Firenze, 28-31 August 1996. Museo Regionale di Scienze Naturali di Torino, Torino, pp. 449-490.

Zhavoronkova T.N. 1969: Certain structural peculiarities of the Carabidae (Coleoptera) in relation to their feeding habits. Entomol. Rev. 48: 462-471.

Received July 30, 2015; revised and accepted March 29, 2016 Published online April 22, 2016 
Appendix 1. Summary of the food preferences of larvae and adults of Italian seed feeding ground beetles, with an indication of the source of the data. Ipe - laboratory preference essay; fo - field observation; $d$ - dissection.

\begin{tabular}{|c|c|c|c|c|c|c|}
\hline Tribe & $\begin{array}{l}\text { Genus/ } \\
\text { subgenus }\end{array}$ & Species & $\begin{array}{l}\text { Diet larvae/ } \\
\text { references }\end{array}$ & Diet adults/references & $\begin{array}{l}\text { Diet adults/ } \\
\text { unpubl. data }\end{array}$ & References \\
\hline $\begin{array}{l}\text { Scaritinae, } \\
\text { Clivinini, } \\
\text { Clivinina }\end{array}$ & Clivina & C. fossor & & Z. mays & & Lundgren, 2009 \\
\hline $\begin{array}{l}\text { Trechinae, } \\
\text {-ni, Trechina }\end{array}$ & $\begin{array}{l}\text { Trechus, } \\
\text { subg. } \\
\text { Trechus }\end{array}$ & T. quadristriatus & & C. bursa-pastoris & & $\begin{array}{l}\text { Honek et al., 2003; Honek \& } \\
\text { Martinkova, 2001; Lundgren et al., } \\
2009\end{array}$ \\
\hline $\begin{array}{l}\text { Pterostichinae, } \\
\text {-ni, Poecilina }\end{array}$ & $\begin{array}{l}\text { Poecilus, } \\
\text { subg. Poecilus }\end{array}$ & ${ }_{S}$ P. cupreus & & $\begin{array}{l}\text { Taraxacum, } P \text {. annua, } \\
\text { C. arvense, C. bursa-pastoris }\end{array}$ & & $\begin{array}{l}\text { Goldschmidt \& Toft, 1997; } \\
\text { Honek et al., 2003, } 2009\end{array}$ \\
\hline $\begin{array}{l}\text { Pterostichinae, } \\
\text {-ni, Molopina }\end{array}$ & $\begin{array}{l}\text { Abax, } \\
\text { subg. Abax }\end{array}$ & $\begin{array}{l}\text { A. } \\
\text { parallelepipedus }\end{array}$ & & Germinating seeds & & Larochelle, 1990 \\
\hline $\begin{array}{l}\text { Pterostichinae, } \\
\text {-ni,Pterostichina }\end{array}$ & $\begin{array}{l}\text { Pterostichus, } \\
\text { subg. } \\
\text { Morphnosoma }\end{array}$ & M. melanarius & & Grass seeds & & $\begin{array}{l}\text { Johnson \& Cameron, 1969; Larochelle, } \\
\text { 1990; Honek et al., } 2003\end{array}$ \\
\hline \multirow[t]{23}{*}{$\begin{array}{l}\text { Pterostichinae, } \\
\text { Zabrini }\end{array}$} & $\begin{array}{l}\text { Amara, } \\
\text { subg. Zezea }\end{array}$ & & & & & $\begin{array}{l}\text { Toft \& Bilde, 2002; Mauchline et al., } \\
\text { 2005; Honek et al., } 2007\end{array}$ \\
\hline & & Z. plebeja & & $\begin{array}{l}\text { Poa, Festuca, Alopecurus geniculatus, } \\
\text { Deschampsia caespitosa, cereals }\end{array}$ & & Lindroth, 1945; Saska et al., 2008 \\
\hline & $\begin{array}{l}\text { subg. } \\
\text { Leiromorpha }\end{array}$ & L. uhligi & & & $\begin{array}{l}\text { vegetable } \\
\text { remains }(d)\end{array}$ & \\
\hline & $\begin{array}{l}\text { subg. } \\
\text { Curtonotus }\end{array}$ & C. aulica & $\begin{array}{l}\text { Artemisia vulgaris, } \\
\text { Tripleurospermum } \\
\text { inodorum, Urtica } \\
\text { dioica, Cirsium } \\
\text { arvense }\end{array}$ & $\begin{array}{l}\text { T. molitor, C. arvense, C. heterophyllum, } \\
\text { C. oleraceum, C. palustre, Carduus crispus, } \\
\text { C. nutans, Taraxacum, Solidago virgaurea, } \\
\text { Centaurea jacea, C. nigra, Achillea } \\
\text { millefolium, Arctium, Leontodon, Tussilago, } \\
\text { Inula, Fagopyrum, Capsella, Alopecurus } \\
\text { pratensis }\end{array}$ & $\begin{array}{l}\text { vegetable } \\
\text { remains }(\mathrm{d}) \\
\text { refuses } \\
\text { Daucus (Ipe) }\end{array}$ & $\begin{array}{l}\text { Lindroth, } 1945 \\
\text { Saska, } 2005 \\
\text { Lundgren, } 2009\end{array}$ \\
\hline & & $\begin{array}{l}\text { C. convexius- } \\
\text { cula }\end{array}$ & $\begin{array}{l}\text { A. vulgaris, } \\
\text { T. inodorum }\end{array}$ & $\begin{array}{l}\text { T. molitor, U. dioica, C. arvense, Salicornia, } \\
\text { ripening seeds of Hordeum } \\
\text { and Fragaria, a seed mixture }\end{array}$ & & $\begin{array}{l}\text { Lindroth, 1945; Saska, 2005; } \\
\text { Honek et al., 2005; Lundgren, } 2009\end{array}$ \\
\hline & $\begin{array}{l}\text { subg. } \\
\text { Bradytus }\end{array}$ & B. fulva & & $\begin{array}{l}\text { Grass seeds, potato stems } \\
\text { Persicaria maculosa }\end{array}$ & & $\begin{array}{l}\text { Lindroth, } 1945 \\
\text { Kolesnikov \& Malueva, } 2015\end{array}$ \\
\hline & & B. apricaria & & Prefers Hyperodes larvae to seeds & & $\begin{array}{l}\text { Johnson \& Cameron, } 1969 \\
\text { Lundgren, } 2009\end{array}$ \\
\hline & subg. Amara & A. communis & & Principally granivorous, Z. mays & $\begin{array}{l}\text { vegetable } \\
\text { remains }(d)\end{array}$ & $\begin{array}{l}\text { Burakowski, 1967; Brandmayr, 1972; } \\
\text { Larochelle, 1990; Hůrka \& Jarošik, } \\
2001\end{array}$ \\
\hline & & A. aenea & $\begin{array}{l}\text { Triticum, Zea mays, } \\
\text { Glycine max, C. } \\
\text { arvense, Poa annua, } \\
\text { mixed diet (seeds } \\
\text { and insects) }\end{array}$ & $\begin{array}{l}\text { C. bursa-pastoris, S. media, Plantago major, } \\
\text { Tussilago farfara, U. dioca, } \\
\text { Potentilla argentea }\end{array}$ & & $\begin{array}{l}\text { Saska \& Jarošík, 2001; Hůrka \& } \\
\text { Jarošík, 2003; Honek et al., 2003, } \\
\text { 2005; Klimes \& Saska, 2010; } \\
\text { Lundgren, 2009; } \\
\text { Saska et al., 2010 }\end{array}$ \\
\hline & & A. anthobia & & Seed mixture & & Honek et al., 2005 \\
\hline & & A. eurynota & $\begin{array}{l}\text { A. vulgaris, } \\
\text { T. inodorum, } \\
\text { U. dioica }\end{array}$ & $\begin{array}{l}\text { Principally granivorous, stamen } \\
\text { of Scabiosa, Anthriscus silvestris, } \\
\text { C. bursa-pastoris, a seed mixture }\end{array}$ & & $\begin{array}{l}\text { Lindroth, 1945; Brandmayr, 1972; } \\
\text { Saska, 2004; Honek et al., 2005; } \\
\text { Zhavoronkova, } 1969\end{array}$ \\
\hline & & A. similata & $\begin{array}{l}\text { Capsella bursa- } \\
\text { pastoris, } T \text {. } \\
\text { inodorum, Papaver } \\
\text { rhoeas, Taraxacum, } \\
\text { Trifolium repens, } \\
\text { P. annua, } \\
\text { Brassica napus, } \\
\text { Cerastium triviale, } \\
\text { Chenopodium } \\
\text { album, C. arvense, } \\
\text { a seed mixture }\end{array}$ & $\begin{array}{l}\text { S. media, flowers of Barbaraea vulgaris, } \\
\text { fruits of Deschampsia flexuosa, Taraxacum, } \\
\text { Trifolium repens, P. annua, Brassica napus, } \\
\text { Cerastium triviale, Chenopodium album, } \\
\text { Triticum, Nasturtium, Reseda luteola, } \\
\text { Cynosurus cristatus, } \\
\text { C. arvense }\end{array}$ & & $\begin{array}{l}\text { Burmeister, } 1939 \\
\text { Lindroth, } 1945 \\
\text { Larochelle, } 1990 \\
\text { Jorgensen \& Toft, 1997a } \\
\text { Saska \& Jarošík, } 2001 \\
\text { Honek et al., 2003, } 2005 \\
\text { Saska, 2008 } \\
\text { Klimes \& Saska, } 2010\end{array}$ \\
\hline & & A. familiaris & Stellaria media & $\begin{array}{l}\text { C. bursa-pastoris, S. media, } \\
\text { C. arvense, C. tomentosum, Z. mays, } \\
\text { P. annua, P. pratensis, seed mixture }\end{array}$ & & $\begin{array}{l}\text { Lindroth, 1945; Saska \& Jarošík, 2001; } \\
\text { Honek et al., 2003, 2005; Saska et } \\
\text { al., 2008; Lundgren, 2009; Klimes \& } \\
\text { Saska, 2010 }\end{array}$ \\
\hline & & A. littorea & & $\begin{array}{l}\text { C. arvense, C. bursa-pastoris } \\
\text { seed mixture }\end{array}$ & & $\begin{array}{l}\text { Honek et al., } 2003,2005 \\
\text { Lundgren, } 2009\end{array}$ \\
\hline & & A. nitida & C. bursa-pastoris & Principally granivory & $\begin{array}{l}\text { vegetable } \\
\text { remains }(d)\end{array}$ & $\begin{array}{l}\text { Brandmayr, 1972; Saska \& Jarošík, } \\
\text { 2001; Honek et al., 2005; Lundgren, } \\
2009\end{array}$ \\
\hline & & A. ovata & & $\begin{array}{l}\text { Flowers and pods of Alliaria, pods } \\
\text { of Barbarea vulgaris and Brassica; seeds } \\
\text { of Reseda luteola, fruits of Cynosurus; } \\
\text { seeds of cereals and crucifers, R. luteola, } \\
\text { C. bursa-pastoris, C. arvense, seed mixture }\end{array}$ & & $\begin{array}{l}\text { Lindroth, } 1945 \\
\text { Honek \& Martinkova, } 2001 \\
\text { Honek et al., 2003, } 2005 \\
\text { Lundgren, } 2009\end{array}$ \\
\hline & & A. montivaga & & $\begin{array}{l}\text { T. officinale preferred } \\
\text { "Dandelion specialist" }\end{array}$ & & Honek et al., 2005 \\
\hline & subg. Celia & C. praetermissa & & Fruits of Solidago virgaurea & & Lindroth, 1945 \\
\hline & & C. bifrons & & $\begin{array}{l}\text { Gutierrezia serothrae, cereals, a seed } \\
\text { mixture }\end{array}$ & & Lindroth, 1945; Honek et al., 2005 \\
\hline & & C. ingenua & & $\begin{array}{l}\text { Polygonum aviculare and another } 9 \text { seed } \\
\text { species, seed mixture }\end{array}$ & & $\begin{array}{l}\text { Lindroth, 1945, 1985-1986; } \\
\text { Honek et al., } 2005\end{array}$ \\
\hline & & C. fusca & & Artemisia campestris & & Lindroth, 1986; Mark Telfer's website \\
\hline & & C. quenseli & & $\begin{array}{l}\text { Wahlbergella affinis, Polygonum aviculare, } \\
\text { Trisetum spicatum, Luzula multiflora, Galium } \\
\text { verum, Thymus serpyllum }\end{array}$ & & $\begin{array}{l}\text { Burmeister, } 1939 \\
\text { Lindroth, 1945, 1985-1986 } \\
\text { Larochelle, 1990 }\end{array}$ \\
\hline & Zabrus & Z. tenebrioides & & $\begin{array}{l}\text { Accepts fresh meat if offered with lettuce } \\
\text { seeds, Triticum, Avena, Hordeum, Secale } \\
\text { a seed mixture }\end{array}$ & & $\begin{array}{l}\text { Gersdorf, } 1937 \text { in Thiele, 1977; } \\
\text { Zhavoronkova, 1969; Honek et al., } \\
\text { 2005, 2007; Pierce, 1971; Bassett, } \\
1978 \text { in Lundgren, } 2009\end{array}$ \\
\hline
\end{tabular}




\begin{tabular}{|c|c|c|c|c|c|c|}
\hline Tribe & $\begin{array}{l}\text { Genus/ } \\
\text { subgenus }\end{array}$ & Species & $\begin{array}{l}\text { Diet larvae/ } \\
\text { references }\end{array}$ & Diet adults/references & $\begin{array}{l}\text { Diet adults/ } \\
\text { unpubl. data }\end{array}$ & References \\
\hline & & Zabrus costai & & & P. bulbosa, (fo) & \\
\hline \multirow[t]{4}{*}{$\begin{array}{l}\text { Harpalinae, } \\
\text { Anisodactylini }\end{array}$} & Scybalicus & S. oblongiusculus & & & $\begin{array}{l}\text { Fresh meat, seeds } \\
\text { of various species, } \\
\text { Daucus, Foeniculum (Ipe) }\end{array}$ & \\
\hline & Anisodactylus & A. binotatus & & Fragaria & Vegetable remains (d) & $\begin{array}{l}\text { Kirchner, 1939; Larochelle, } 1977 \text { in } \\
\text { Lundgren, } 1990\end{array}$ \\
\hline & & A. signatus & & C. arvense, seed mixture & $\begin{array}{l}\text { Daucus, Foeniculum, } \\
\text { Tenebrio, fresh meat (Ipe) }\end{array}$ & Honek et al., 2003, 2005, 2007 \\
\hline & & A. nemorivagus & & & Vegetable remains $(\mathrm{d})$ & \\
\hline \multirow[t]{6}{*}{$\begin{array}{l}\text { Harpalinae, } \\
\text { Stenolophini }\end{array}$} & Bradycellus & $\begin{array}{l}\text { B. (Tetraplatypus) } \\
\text { ganglbaueri }\end{array}$ & & $\begin{array}{l}\text { Satureja montana, S. subspicata, } \\
\text { S. vulgaris, S. juliana, S. hortensis }\end{array}$ & $\begin{array}{l}\text { Meat, S. montana, } \\
\text { S. subspicata, S. vulgari, } \\
\text { S. juliana, S. hortensis } \\
\text { Refuses other seeds (Ipe), } \\
\text { animal remains in gut (d), } \\
\text { S. montana (fo) }\end{array}$ & Zetto Brandmayr \& Brandmayr, 1978a \\
\hline & & $\begin{array}{l}\text { B. (Tetraplatypus) } \\
\text { ruficollis }\end{array}$ & & $\begin{array}{l}\text { Calluna seeds }(67,2 \%) \text { in the ingested } \\
\text { food }\end{array}$ & & Melber, 1983 \\
\hline & & B. (T.) verbasci & & & $\begin{array}{l}\text { Daucus, Ligusticum; } \\
\text { meat (Ipe) }\end{array}$ & \\
\hline & & B. (T.) harpalinus & & Seed heads of Gramineae & & Larochelle, 1990 \\
\hline & Acupalpus & A. flavicollis & & & Vegetable remains $(\mathrm{d})$ & \\
\hline & & A. meridianus & & Seed mixture & & Honek et al., 2005 \\
\hline \multirow[t]{17}{*}{$\begin{array}{l}\text { Harpalinae, } \\
\text {-ni, } \\
\text { Harpalina }\end{array}$} & $\begin{array}{l}\text { Ophonus } \\
\text { subg. Ophonus }\end{array}$ & & $\begin{array}{l}\text { Primarily } \\
\text { granivorous }\end{array}$ & Primarily granivorous & & $\begin{array}{l}\text { Brandmayr et al., 1980, 1990; } \\
\text { Brandmayr \& Zetto Brandmayr, 1982; } \\
\text { Zetto Brandmayr, 1990; Toft \& Bilde, } \\
\text { 2002; Giglio et al., 2008 }\end{array}$ \\
\hline & & O. stictus & & $\begin{array}{l}\text { "granivorous tendencies" } \\
\text { on Daucus heads }\end{array}$ & & $\begin{array}{l}\text { Brandmayr, } 1972 \\
\text { Larochelle, } 1990\end{array}$ \\
\hline & & $\begin{array}{l}\text { O. ardosiacus } \\
\text { (rotundicollis) }\end{array}$ & $\begin{array}{l}\text { Daucus } \\
\text { carota, Seseli, } \\
\text { Foeniculum, } \\
\text { Bupleurum } \\
\text { junceum, } \\
\text { Sium sisarum }\end{array}$ & D. carota, Pastinaca & $\begin{array}{l}\text { Daucus (lpe }+ \text { fo), } \\
\text { Peucedanum, Seseli elatior } \\
\text { Foeniculum, Angelica, } \\
\text { Bupleurum junceum, } \\
\text { Sium sisarum, Tenebrio, } \\
\text { refuses meat (lpe), } \\
\text { vegetable remains (d) }\end{array}$ & $\begin{array}{l}\text { Brandmayr et al., } 1980 \\
\text { Zetto Brandmayr, 1976, 1978, 1980, } \\
1983 \\
\text { Larochelle, } 1990 \\
\text { Zetto Brandmayr, } 1990\end{array}$ \\
\hline & & O. diffinis & $\begin{array}{l}\text { D. carota, } \\
\text { Foeniculum }\end{array}$ & D. carota, Foeniculum & $\begin{array}{l}\text { Daucus, vegetable remains } \\
\text { (d), Daucus (fo), refuses } \\
\text { meat (Ipe) }\end{array}$ & $\begin{array}{l}\text { Zetto Brandmayr, 1976, } 1978 \\
\text { Larochelle, } 1990\end{array}$ \\
\hline & & O. sabulicola & $\begin{array}{l}\text { Seed of } \\
\text { Umbrelliferae }\end{array}$ & Seed of Umbrelliferae & Daucus, F. vulgare (Ipe) & Larochelle, 1990; Alessi, 1995 \\
\hline & $\begin{array}{l}\text { subg. } \\
\text { Hespero- } \\
\text { phonus }\end{array}$ & H. azureus & $\begin{array}{l}\text { Specialists on } \\
\text { seed-heads of } \\
D . \text { carota and } \\
\text { umbellifers, } \\
\text { Foeniculum, } \\
\text { C. bursa-pastoris } \\
\text { Meat sometimes } \\
\text { preferred }\end{array}$ & $\begin{array}{l}\text { Specialists on seed-heads } \\
\text { of } D \text {. carota and umbellifers, } \\
\text { Foeniculum, } \\
\text { C. bursa-pastoris } \\
\text { Meat sometimes preferred } \\
\end{array}$ & $\begin{array}{l}\text { Daucus, meat, } \\
\text { sometimes accepts } \\
\text { meat (Ipe), vegetable } \\
\text { remains (d) }\end{array}$ & $\begin{array}{l}\text { Zetto Brandmayr, 1976, } 1978 \\
\text { Honek et al., 2003, } 2007 \\
\text { Brandmayr et al., } 1980\end{array}$ \\
\hline & $\begin{array}{l}\text { subg. } \\
\text { Metophonus }\end{array}$ & M. cordatus & & D. carota, Foeniculum & $\begin{array}{l}\text { Daucus, Foeniculum (Ipe), } \\
\text { vegetable remains }(\mathrm{d})\end{array}$ & Brandmayr, 1972; Larochelle, 1990 \\
\hline & & M. melleti & & Daucus & Daucus, Foeniculum (Ipe) & Larochelle, 1990 \\
\hline & & M. puncticeps & $\begin{array}{l}\text { D. carota, } \\
\text { Foeniculum }\end{array}$ & D. carota, Foeniculum & $\begin{array}{l}\text { Daucus (Ipe + fo), } \\
\text { Peucedanum, Laserpitium } \\
\text { siler, Sesleria autumnalis, } \\
\text { Foeniculum, Artemisia spp., } \\
\text { Ligusticum, Anthriscus } \\
\text { cerefolius, Sium sisarum, } \\
\text { refuses meat (lpe), } \\
\text { vegetable remains (d) }\end{array}$ & $\begin{array}{l}\text { Brandmayr Zetto \& Brandmayr, } 1975 \\
\text { Zetto Brandmayr, 1976, } 1978 \\
\text { Lundgren, } 2009\end{array}$ \\
\hline & & M. puncticollis & $\begin{array}{l}\text { D. carota, } \\
\text { Foeniculum }\end{array}$ & D. carota, Foeniculum & $\begin{array}{l}\text { Daucus, Peucedanum, } \\
\text { Laserpitium, Sesleria aut., } \\
\text { Plantago spp., refuses meat } \\
\text { (Ipe), vegetable remains (d) }\end{array}$ & Zetto Brandmayr, 1976, 1978 \\
\hline & & M. rupicola & & Specialists on seed-heads of Daucus & Daucus & Larochelle, 1990 \\
\hline & $\begin{array}{l}\text { subg. } \\
\text { Incisophonus }\end{array}$ & I. incisus & & & $\begin{array}{l}\text { Daucus, Foeniculum, } \\
\text { Bupleurum junceum, Silene } \\
\text { vulgaris, Angelica silv., Sium } \\
\text { lancif., Anthriscus silvestris, } \\
\text { refuses meat (Ipe) }\end{array}$ & \\
\hline & Cryptophonus & $\begin{array}{l}\text { Cryptophonus } \\
\text { tenebrosus }\end{array}$ & $\begin{array}{l}\text { D. carota, } \\
\text { Foeniculum }\end{array}$ & & $\begin{array}{l}\text { Daucus, Foeniculum, } \\
\text { refuses meat }(\mathrm{lpe}) \\
\text { vegetable remains }(\mathrm{d})\end{array}$ & $\begin{array}{l}\text { Brandmayr \& Zetto Brandmayr, 1980, } \\
1982\end{array}$ \\
\hline & $\begin{array}{l}\text { Pseudo } \\
\text {-ophonus } \\
\text { subg. } \\
\text { Pseudo } \\
\text {-ophonus }\end{array}$ & $\begin{array}{l}\text { Pseudoophonus } \\
\text { rufipes } \\
\text { (pubescens } \\
\text { auctorum) }\end{array}$ & $\begin{array}{l}\text { T. officinale, } \\
\text { Chenopodium } \\
\text { album, Sinapis } \\
\text { arvensis, S. } \\
\text { media, Polygo- } \\
\text { num aviculare, } \\
\text { a seed mixture } \\
\text { "seed consumers" }\end{array}$ & $\begin{array}{l}\text { T. officinale, Chenopodium } \\
\text { album, Sinapis arvensis, } \\
\text { S. media, Polygonum aviculare, } \\
\text { a seed mixture } \\
\text { "seed consumers" }\end{array}$ & $\begin{array}{l}\text { Vegetable and animal } \\
\text { remains (d) }\end{array}$ & $\begin{array}{l}\text { Briggs, 1965; Larochelle, 1990; } \\
\text { Jørgensen \& Toft, 1997b; Honek et al., } \\
\text { 2003, 2005; Martinkova et al., 2006; } \\
\text { Saska et al., 2008, 2010; for a complete } \\
\text { list of seeds and authors see Lundgren, } \\
2009\end{array}$ \\
\hline & & P. griseus & & Fragaria & & Larochelle, 1990 \\
\hline & Harpalus & & & & & $\begin{array}{l}\text { Zetto Brandmayr, 1990; Toft \& Bilde, } \\
\text { 2002; Lundgren, } 2009\end{array}$ \\
\hline & & H. honestus & $\begin{array}{l}\text { Meat, Orthoptera, } \\
\text { Tenebrio molitor, } \\
\text { Peucedaum, } \\
\text { Daucus, araxacum }\end{array}$ & & & $\begin{array}{l}\text { Bertrandi \& Zetto Brandmayr, } 1991 \\
\text { Zetto Brandmayr, } 1990\end{array}$ \\
\hline
\end{tabular}




\begin{tabular}{|c|c|c|c|c|c|c|}
\hline Tribe & $\begin{array}{l}\text { Genus/ } \\
\text { subgenus }\end{array}$ & Species & $\begin{array}{l}\text { Diet larvae/ } \\
\text { references }\end{array}$ & Diet adults/references & $\begin{array}{l}\text { Diet adults/ } \\
\text { unpubl. data }\end{array}$ & References \\
\hline & & H. anxius & & & $\begin{array}{l}\text { Vegetable and animal } \\
\text { remains (d) }\end{array}$ & \\
\hline & & H. dimidiatus & Daucus & "granivorous tendencies" & $\begin{array}{l}\text { Daucus, Foeniculum, } \\
\text { Tenebrio, fresh meat (Ipe) } \\
\text { vegetable and animal } \\
\text { remains (d) }\end{array}$ & $\begin{array}{l}\text { Brandmayr, } 1972 \\
\text { Larochelle, } 1990 \\
\text { Bertrandi \& Zetto Brandmayr, } 1991\end{array}$ \\
\hline & & $\begin{array}{l}\text { H. affinis } \\
\text { (aeneus } \\
\text { auctorum) }\end{array}$ & $\begin{array}{l}\text { Daucus, } \\
\text { Foeniculum }\end{array}$ & $\begin{array}{l}\text { Picea, Fragaria, S. media, T. officinalis, } \\
\text { D. sanguinalis, Trifolium pratense, } \\
\text { Cerastium arvense, C. bursa-pastoris, } \\
\text { P. annua, Cirsium album, C. arvense, } \\
\text { seed mixture, Daucus, Foeniculum }\end{array}$ & & $\begin{array}{l}\text { Bertrandi \& Zetto Brandmayr, } 1991 \\
\text { Honek et al., 2003, 2005, } 2006 \\
\text { Martinkova et al., } 2006 \\
\text { Saska et al., } 2008 \\
\text { Lundgren, } 2009\end{array}$ \\
\hline & & H. atratus & $\begin{array}{l}\text { D. carota, } \\
\text { a seed mixture }\end{array}$ & Shrubby trees, C. arvense & & $\begin{array}{l}\text { Larochelle, 1990; Bertrandi \& Zetto } \\
\text { Brandmayr, 1991; Honek et al., 2003, } \\
2005\end{array}$ \\
\hline & & H. luteicornis & & Seed mixture & & Honek et al., 2005 \\
\hline & & H. servus & & $\begin{array}{l}\text { Secale, Hordeum, Camelina sativa, } \\
\text { forest trees }\end{array}$ & & Larochelle, 1990 \\
\hline & & $\begin{array}{l}\text { H. solitaris } \\
\text { (fuliginosus } \\
\text { auctt.) }\end{array}$ & & Carex pitulifera & & Kjellsson, 1985 in Lundgren, 2009 \\
\hline & & H. tardus & D. carota & C. arvense, C. bursa-pastoris & & $\begin{array}{l}\text { Bertrandi \& Zetto Brandmayr, } 1991 \\
\text { Honek \& Martinkova, } 2001 \\
\text { Honek et al., 2003, } 2005\end{array}$ \\
\hline & & H. marginellus & & "granivorous tendencies" & $\begin{array}{l}\text { Vegetable and animal } \\
\text { remains }(d)\end{array}$ & Brandmayr, 1972; Larochelle, 1990 \\
\hline & & H. rubripes & & Daucus, Foeniculum & $\begin{array}{l}\text { Meat (Ipe), Vegetable } \\
\text { remains (d) }\end{array}$ & $\begin{array}{l}\text { Brandmayr, 1972; Bertrandi \& Zetto } \\
\text { Brandmayr, 1991; Larochelle, } 1990\end{array}$ \\
\hline & & H. sulphuripes & & Foeniculum, Triticum, meat & & Bertrandi \& Zetto Brandmayr, 1991 \\
\hline & & H. distinguendus & & $\begin{array}{l}\text { Fragaria, P. annua, Daucus, S. } \\
\text { media, C. arvense, C. bursa-pastoris, } \\
\text { Foeniculum, Triticum, Taraxacum, Linum, } \\
\text { Peucedanum, cereals, a seed mixture }\end{array}$ & $\begin{array}{l}\text { Fresh meat (Ipe) } \\
\text { Daucus, Foeniculum (fo) }\end{array}$ & $\begin{array}{l}\text { Bertrandi \& Zetto Brandmayr, } 1991 \\
\text { Larochelle, } 1990 \\
\text { Honek \& Martinkova, } 2001 \\
\text { Honek et al., 2003, 2005, } 2006\end{array}$ \\
\hline & & H. serripes & & & $\begin{array}{l}\text { vegetable and animal } \\
\text { remains }(\mathrm{d}) \\
\text { Bromus erectus (fo) }\end{array}$ & \\
\hline & $\begin{array}{l}\text { subg. } \\
\text { Semiophonus }\end{array}$ & S. signaticornis & & $\begin{array}{l}\text { Oat flakes and pieces of } T \text {. molitor } \\
\text { larvae, C. arvense, C. bursa pastoris, } \\
\text { seed mixture }\end{array}$ & & $\begin{array}{l}\text { Hůrka, } 1992 \\
\text { Honek \& Martinkova, } 2001 \\
\text { Honek et al., 2003, } 2005\end{array}$ \\
\hline & $\begin{array}{l}\text { subg. } \\
\text { Harpalophonus }\end{array}$ & $\begin{array}{l}\text { H. circumpunta- } \\
\text { tus ssp. italus }\end{array}$ & $\begin{array}{l}\text { Meat, seeds, } \\
\text { Tenebrio molitor }\end{array}$ & & $\begin{array}{l}\text { Daucus, Foeniculum, } \\
\text { Tenebrio, meat (lpe) }\end{array}$ & Zetto Brandmayr \& Brandmayr, 1978b \\
\hline & $\begin{array}{l}\text { Acinopus, } \\
\text { subg. Acinopus }\end{array}$ & A. picipes & & seeds & $\begin{array}{l}\text { D. carota, F. vulgare, } \\
\text { T. aestivum, meat (Ipe) }\end{array}$ & Barbieri, 1998; Larochelle, 1990 \\
\hline & subg. Osimus & O. ammophilus & & Medicago minima seeds & & $\begin{array}{l}\text { Burmeister 1939; Larochelle, 1990; } \\
\text { Honek et al., } 2005\end{array}$ \\
\hline & Daptus & D. vittatus & & & $\begin{array}{l}\text { Fresh chicken meat (pers. } \\
\text { comm. of G. Colombetta) }\end{array}$ & \\
\hline & Trichotichnus & T. laevicollis & & & $\begin{array}{l}\text { Fresh meat, Pimpinella sp. } \\
\text { (Ipe) }\end{array}$ & \\
\hline & Parophonus & P. maculicornis & & A seed mixture & $\begin{array}{l}\text { Fresh meat, seed mixture } \\
\text { (Ipe) }\end{array}$ & Lundgren, 2009 \\
\hline & & P. mendax & & & $\begin{array}{l}\text { Fresh meat, seed mixture } \\
\text { (Ipe) }\end{array}$ & \\
\hline \multirow[t]{7}{*}{$\begin{array}{l}\text { Harpalinae, } \\
\text {-ni, } \\
\text { Ditomina }\end{array}$} & $\begin{array}{l}\text { Ditomus } \\
(=\text { Sabienus })\end{array}$ & $\begin{array}{l}\text { Ditomus } \\
\text { (= Sabienus) } \\
\text { calydonius }\end{array}$ & $\begin{array}{l}\text { D. gingidium } \\
\text { polygamus, two } \\
\text { nests observed } \\
\text { in nature }\end{array}$ & Daucus, nest observed in nature & $\begin{array}{l}\text { Accepts especially } D \text {. carota } \\
\text { seeds, also unripe, nest } \\
\text { observed in laboratory } \\
\text { refuses meat (lpe + fo) }\end{array}$ & $\begin{array}{l}\text { Brandmayr \& Zetto Brandmayr, 1974, } \\
\text { 1987; Brandmayr, 1974; Brandmayr } \\
\text { et al., 1994; Zetto Brandmayr, 1990; } \\
\text { Zetto Brandmayr et al., } 1994\end{array}$ \\
\hline & & $\begin{array}{l}\text { D. (S.) } \\
\text { tricuspidatus }\end{array}$ & & Ammi majus & & $\begin{array}{l}\text { Burmeister, } 1939 \\
\text { Larochelle, } 1990\end{array}$ \\
\hline & Dixus & $\begin{array}{l}\text { D. } \\
\text { sphaerocephalus }\end{array}$ & & Plantago cornuti, P. crassifolia & & $\begin{array}{l}\text { Larochelle, } 1990 \\
\text { Therond, } 1975 \text { in Lundgren, } 2009\end{array}$ \\
\hline & & Dixus clypeatus & $\begin{array}{l}\text { Plantago } \\
\text { lanceolata, nest } \\
\text { observed in } \\
\text { nature, no larvae } \\
\text { observed at } \\
\text { feeding }\end{array}$ & $\begin{array}{l}\text { Plantago lanceolata, nest observed } \\
\text { in nature, grass }\end{array}$ & & $\begin{array}{l}\text { Schremmer, } 1960 \\
\text { Brandmayr \& Zetto Brandmayr, } 1987 \\
\text { Larochelle, } 1990\end{array}$ \\
\hline & $\begin{array}{l}\text { Tschitsche- } \\
\text { rinellus }\end{array}$ & T. cordatus & & & $\begin{array}{l}\text { Lives in dense stans of } \\
\text { Daucus gingidium garigues } \\
\text { and feeds on this species } \\
\text { (Ipe+fo) }\end{array}$ & \\
\hline & Carterus & C. fulvipes & & $\begin{array}{l}\text { Mass swarming from seed cropland } \\
\text { in Italy, Daucus, Pimpinella, Apium, } \\
\text { Plantago (fo) }\end{array}$ & & $\begin{array}{l}\text { Larochelle, } 1990 \\
\text { Fabbri \& Contarini, } 2009\end{array}$ \\
\hline & & C. dama & & $\begin{array}{l}\text { Mass swarming from anise seed } \\
\text { cropland, } P \text {. anisum }\end{array}$ & $\begin{array}{l}\text { Kept in the lab on Daucus } \\
\text { seeds, refuses meat (lpe) }\end{array}$ & Koçak et al., 2007 \\
\hline $\begin{array}{l}\text { Platyninae, } \\
\text { Sphodrini, } \\
\text { Calathina }\end{array}$ & $\begin{array}{l}\text { Calathus } \\
\text { subg. Calathus }\end{array}$ & C. fuscipes & & Picea, Triticum, C. bursa-pastoris & & $\begin{array}{l}\text { Larochelle, } 1990 \\
\text { Goldscmidt \& Toft, } 1997 \\
\text { Honek \& Martinkova, } 2001\end{array}$ \\
\hline $\begin{array}{l}\text { Platyninae, } \\
\text { Platynini }\end{array}$ & Agonum & A. mülleri & & C. bursa-pastoris, P. annua & & Saska et al., 2008 \\
\hline
\end{tabular}

